\title{
A Combined Cross-sectional and Longitudinal Study on Predicting Metabolic Syndrome and Cardiovascular Disease by Using Haemoglobin in the Elderly \\ T-H Chao ${ }^{1,2}$, Y-H Hu${ }^{3}$, P-C Liang 4 , S-W Kuo ${ }^{5}$, D-A Wu
}

\begin{abstract}
Background: Metabolic syndrome (MetS) has an important implication from a preventive medicine perspective as an early recognition and intervention would likely reduce associated mortality and morbidty To better identify the patients at risk for developing MetS and cardiovascular diseases, we conducted a combined cross-sectional and longitudinal study to shed light on the elevated haemoglobin (Hb) level in the elderly.

Methods: A total of 10579 subjects were eligible for analyses. In the first part of the study, the subjects were enrolled in the cross-sectional study to find out not only the correlation between $\mathrm{Hb}$ and MetS but also the best cut-off point for $\mathrm{Hb}$ with greater chances of having MetS. In the second part of the study, we excluded the subjects with MetS at the baseline from the same study group and performed a median 5.8-year longitudinal study.

Results: Haemoglobin was significantly higher in the group with MetS than in the group without for both genders. All the MetS components were associated with Hb in multivariant analyses except highdensity lipoprotein (HDL) and systolic blood pressure (SBP). In the longitudinal study, Hb was shown to be a good predictor of MetS in both genders. Moreover, $\mathrm{Hb}$ was also a good predictor of future cardiovascular diseases, only in women with a hazard ratio of 1.293.

Conclusion: This study suggests that elevated $\mathrm{Hb}$ at a cut-off value of 14.6 and 13.7 for the males and the females, respectively, was associated with MetS. Therefore, Hb can potentially be used as a marker to stratify the risks of developing MetS for both genders, and cardiovascular diseases in the female population.
\end{abstract}

Keywords: Elderly, haemoglobin, longitudinal, metabolic syndrome

\section{Estudio Transversal y Longitudinal Combinado sobre la Predicción del Síndrome Metabólico y la enfermedad Cardiovascular Mediante el uso de la Haemoglobina en los Ancianos \\ T-H Chao ${ }^{1,2}$, Y-H Hu${ }^{3}$, P-C Liang ${ }^{4}$, S-W Kuo ${ }^{5}$ D-A Wu ${ }^{5}$}

\begin{abstract}
RESUMEN
Antecedentes: El síndrome metabólico (SMet) tiene una importante implicación desde la perspectiva de la medicina preventiva, puesto que un reconocimiento e intervención tempranos probablemente reduciría la mortalidad y morbilidad que le están asociadas. Para lograr una mejor identificación de los pacientes en riesgo de desarrollar SMet y enfermedades cardiovasculares, se realizó un estudio transversal $y$ longitudinal combinado con el fin de arrojar luz sobre el nivel elevado de haemoglobina (Hb) en los ancianos.

Métodos: Un total de 10,579 sujetos fueron elegibles para el análisis. En la primera parte del estudio, los sujetos fueron enrolados en el estudio transversal buscando encontrar no sólo la correlación entre Hb y SMet, sino también el mejor punto de corte en el cual la Hb tiene mayores probabilidades de desarro-
\end{abstract}

From: ${ }^{1}$ Department of Neurology and ${ }^{2}$ Deparment of Geriatric Medicine, Cardinal Tien Hospital, School of Medicine, Fu-Jen Catholic University, New Taipei, Taiwan, ${ }^{3}$ Taipei Tzu Chi Hospital, Buddhist Tzu Chi Medical Foundation, 289 Jianguo Road, 231 Xindian City, Taipei Country, Taiwan, ${ }^{4}$ Department of Internal medicine, Western Connecticut Health Network-Danbury Hospital, 24 Hospital Ave Danbury, CT, USA and ${ }^{5}$ Department of Internal
Medicine, Division of Endocrinology and Metabolism, Buddhist Tzu Chi General Hospital, Hualieni, Taiwan.

Correspondence: Dr D-A Wu, Division of Endocrinology and Metabolism, Department of Internal Medicine, Buddhist Tzu Chi General Hospital, Hualieni, Taiwan, No 289, Jianguo Rd, Xindian District, New Taipei City 23142, Taiwan (R.O.C.).Email: wangjj59@yahoo.com 
llo del SMet. En la segunda parte de nuestro estudio, excluimos los sujetos con SMet en la línea de base, del mismo grupo de estudio y realizamos un estudio longitudinal de 5.8 años promedio.

Resultados: La haemoglobina fue significativamente mayor en el grupo con SMet que en el grupo sin SMet para ambos sexos. Todos los componentes de SMet estuvieron asociados con Hb en los análisis multivariantes, excepto la lipoproteína de alta densidad (LAD) y la presión arterial sistólica (PAS). En el estudio longitudinal, se halló que Hb es un buen predictor del SMet en ambos sexos. Además, Hb fue también un buen predictor de futuras enfermedades cardiovasculares, sólo en mujeres con un cociente de riesgo de 1.293 .

Conclusión: Nuestro estudio sugiere que una Hb elevado en un valor de corte de 14.6 y 13.7 para varones y hembras, respectivamente, se halla asociada con el SMet. Por lo tanto, Hb puede potencialmente utilizarse como marcador para estratificar el riesgo de desarrollar SMet para ambos géneros, y enfermedades cardiovasculares en la población femenina.

Palabras claves: Mayores de edad, haemoglobina, síndrome metabólico, longitudinal

West Indian Med J 2017; 66 (1): 66

\section{INTRODUCTION}

Hypertension, hyperlipidaemia, hyperglycaemia and central obesity are conditions that may co-exist more often than by chance alone; thus, the term metabolic syndrome (MetS) is used to describe this constellation of metabolic disturbance (1). Although different diagnostic criteria have been proposed, the essential components of MetS remain unchanged (1-3). The diagnoses of MetS have important implications from the preventive medicine perspective as it is associated with diabetes mellitus and cardiovascular diseases $[\mathrm{CVD}](4,5)$.

Early recognition and intervention of MetS are likely to reduce the patients' mortality and morbidity. The acknowledgements of the risk factors for MetS are also important, and they include: older age, postmenopausal status, current smoking, genetic predisposition and physical inactivity etc (6). The current pathogenesis for MetS suggests the involvement of proinflammatory, prothrombotic and insulin resistance and hyperinsulin state (1).

Numerous studies have demonstrated the association between MetS and inflammatory markers such as C-reactive protein, ferritin, haptoglobin, platelet and white blood cell and prothrombotic markers such as fibrinogen as well as haemoglobin $(\mathrm{Hb})$ and erythropoietin level (7-10). Nevertheless, the majority of these studies were cross-sectional, therefore, a causal relationship cannot be firmly established.

To evaluate the association between $\mathrm{Hb}$ and MetS, we first performed a cross-sectional study comparing the $\mathrm{Hb}$ levels of patients with and without metabolic syndrome. In addition, a cut-off point of $\mathrm{Hb}$ with higher chances of having MetS was determined. Then, we conducted a longitudinal study in an attempt to validate if an elevated $\mathrm{Hb}$ is a risk factor for developing a metabolic syndrome. Since an elevated $\mathrm{Hb}$ level has been shown to be associated with CVD (11), we further investigated this association in our longitudinal study.

\section{SUBJECTS AND METHODS}

\section{Study sample}

Subjects aged 60 years and older who underwent routine health checkups at the MJ Health Screening Centre in Taiwan were enrolled. MJ Health Screening Centres are a privately-owned chain of clinics located throughout Taiwan that provide regular health examinations to their members. All the study's participants were anonymous and informed consent was obtained from them. Data were provided by MJ Health Screening Centre for research purposes only and the institutional review board of MJ Health Screening Centre approved the study's protocol.

We randomly selected 21637 records from MJ Health Screening Centre's database between 1999 and 2007. Subjects with a past history of hypertension, diabetes and cardiovascular event and subjects taking medications known to affect the MetS components were all excluded $(n=8423)$. In addition, we excluded the subjects who visited only once $(n=2418)$ and had missing data of the MetS components $(n=217)$. Finally, a total of 10579 subjects were eligible for analyses (Fig. 1).

In the first part of the study, subjects were enrolled in the cross-sectional study to find out not only the association between $\mathrm{Hb}$ and MetS but also the best cut-off point of $\mathrm{Hb}$ in predicting the concurrence of MetS. In the second part of our study, we excluded 2861 subjects with MetS at the baseline from the same study group and performed the longitudinal study with 7718 subjects followed from the first to the ninth year (median 5.8 years). This part of the study was to validate whether the cut-off point for $\mathrm{Hb}$ at the baseline can successfully predict the development of MetS.

\section{Anthropometric measurements and general data}

Members of the senior nursing staff used a questionnaire to obtain the subjects' medical history, including any current medications. Complete physical examinations were performed. Waist circumference (WC) was measured horizontally at the level of the natural waist, which was identified as the level at the hollow molding of the trunk when the trunk was laterally concave. Body mass index (BMI) was calculated as the subject's bodyweight $(\mathrm{kg})$ divided by the square of the subject's height (m). Both systolic blood pressure (SBP) and diastolic blood pressure (DBP) were measured by the nursing staff using standard mercury sphygmomanometers fitted on the 


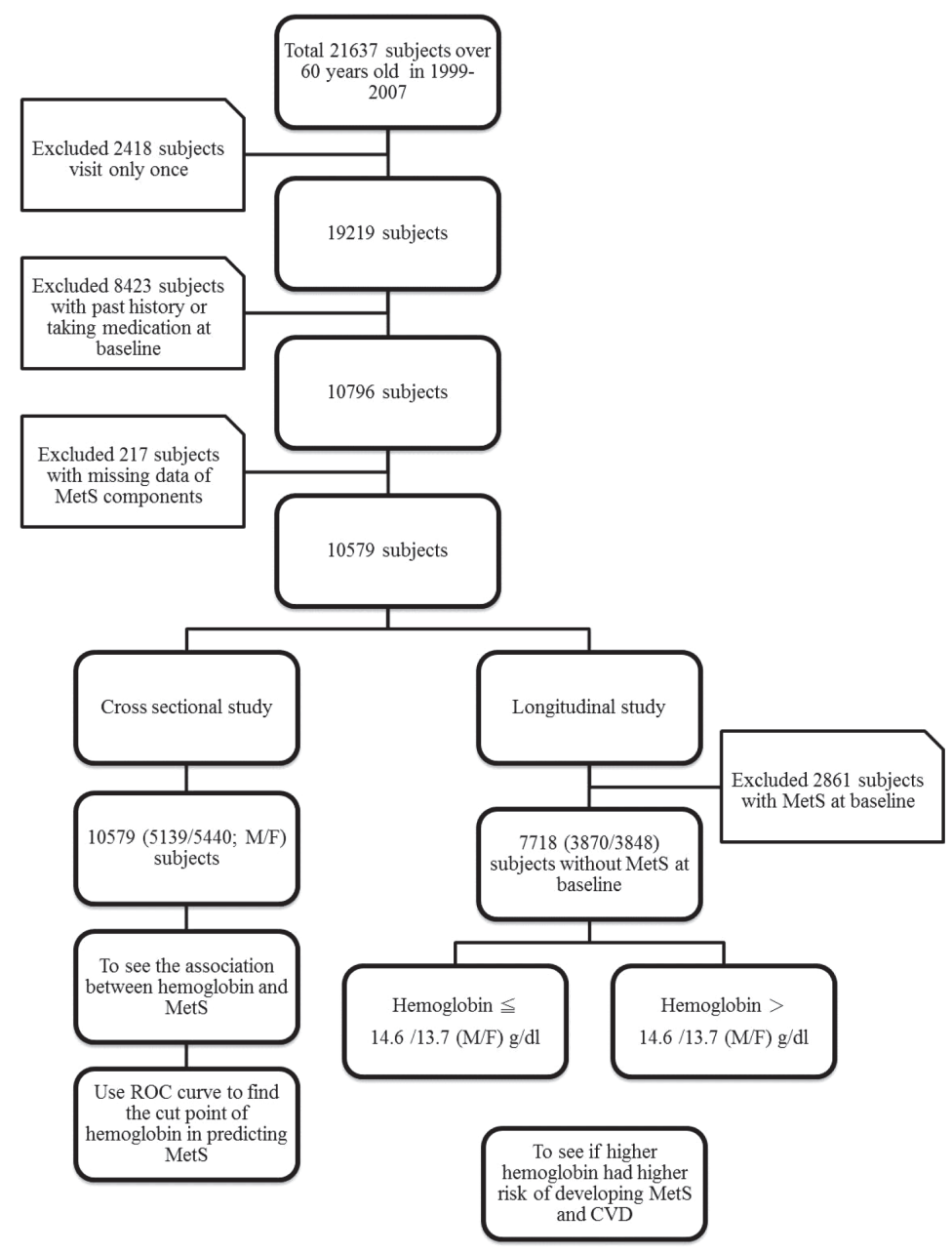

Fig. 1: Description of the study design.

right arm of each subject when seated. After the subjects fasted for 10 hours, blood samples were taken from the antecubital vein for biochemical analyses. Plasma was separated from the blood within one hour and stored at $-30{ }^{\circ} \mathrm{C}$ and analysed for fasting plasma glucose (FPG) and lipid profiles. The FPG was detected using a glucose oxidase method (YSI 203 glucose analyzer, Scientific Division, Yellow Springs Instruments, Yellow Springs, $\mathrm{OH}$ ). The total cholesterol and triglycerides (TG) were measured using the dry, multilayer analytical slide method in the Fuji Dri-Chem 3000 analyser (Fuji Photo Film, Minato-Ku, Tokyo, Japan). Serum high-density lipoprotein cholesterol (HDL-C) and low-density lipoprotein cholesterol (LDL-C) concentration were analysed using an enzymatic cholesterol assay following dextran sulphate precipitation. Haemoglobin was measured with an Abbott Cell Dyn 3000 haematology analyser (Abbott Laboratories, Abbott Park, IL, USA).

\section{Definition of MetS}

We used the latest harmonized criteria of MetS in 2009 (3) with some modifications. Waist circumference $\geq 90$ and $80 \mathrm{~cm}$ in
Taiwanese men and women, respectively was used (12). Other four criteria were the same: $\mathrm{SBP} \geq 130 \mathrm{mmHg}$ or DBP $\geq 85 \mathrm{mmHg}, \mathrm{TG} \geq 150 \mathrm{mg} / \mathrm{dL}, \mathrm{FPG} \geq 100 \mathrm{mg} / \mathrm{dL}, \mathrm{HDL} \leq 40$ and $50 \mathrm{mg} / \mathrm{dL}$ in men and women, respectively or taking relative medications. The subjects had to have at least three criteria to be diagnosed as MetS.

\section{Statistical analyses}

All the statistical analyses were done using SPSS 18.0 software (SPSS Inc., Chicago, IL). The data were presented as mean \pm standard deviation. All the data were tested for normal distribution with Kolmogorov-Smirnov test and for homogeneity of variances with Levene's test. The $t$-test was used to determine the differences between the two groups. The correlations between MetS associated components and $\mathrm{Hb}$ were determined using the Pearson correlation. Multivariate linear regression analysis was performed to further confirm if $\mathrm{Hb}$ was independently related to MetS. The optimal cut-off point was calculated using the receiver operating characteristic (ROC) curves (MedCalc Software, Broekstraat, Mariakerke, Belgium). Kaplan-Meier plot and log rank test were done to de- 
termine the differences among the different $\mathrm{Hb}$ levels at the baseline. Finally, cox regression was performed to determine the hazard ratio (HR) of the two different groups during the follow-up period. A $p$-value (two-sided) $<0.05$ was considered to be significant.

\section{RESULTS}

The demographic data of this study's participants could be seen in Table 1.

Table 1: Demographic data of subjects with and without metabolic syndrome

\begin{tabular}{|c|c|c|c|}
\hline & MetS (-) & MetS (+) & $p$ \\
\hline \multicolumn{4}{|l|}{ Male } \\
\hline $\mathrm{n}$ & 3870 & 1269 & \\
\hline Age (years) & $64.8 \pm 5.2$ & $65.1 \pm 5.4$ & 0.125 \\
\hline Body mass index $\left(\mathrm{kg} / \mathrm{m}^{2}\right)$ & $22.90 \pm 2.58$ & $25.72 \pm 2.74$ & $<0.001$ \\
\hline Waist circumference $(\mathrm{cm})$ & $81.6 \pm 7.5$ & $90.8 \pm 7.6$ & $<0.001$ \\
\hline Systolic blood pressure (mmHg) & $125.4 \pm 17.8$ & $138.1 \pm 17.1$ & $<0.001$ \\
\hline Diastolic blood pressure (mmHg) & $74.4 \pm 10.6$ & $81.1 \pm 11.0$ & $<0.001$ \\
\hline Fasting Plasma Glucose (mg/dL) & $99.7 \pm 14.5$ & $112.3 \pm 30.8$ & $<0.001$ \\
\hline Total cholesterol (mg/dL) & $200.3 \pm 34.8$ & $204.0 \pm 36.3$ & $<0.001$ \\
\hline HDL-C (mg/dL) & $53.0 \pm 13.1$ & $41.3 \pm 10.5$ & $<0.001$ \\
\hline LDL-C (mg/dL) & $126.6 \pm 31.5$ & $126.8 \pm 32.2$ & 0.884 \\
\hline Triglyceride (mg/dL) & $103.5 \pm 47.4$ & $179.4 \pm 73.0$ & $<0.001$ \\
\hline $\log \mathrm{TG}$ & $1.98 \pm 0.18$ & $2.20 \pm 0.23$ & $<0.001$ \\
\hline Haemoglobin (g/dL) & $14.79 \pm 1.22$ & $15.14 \pm 1.26$ & $<0.001$ \\
\hline \multicolumn{4}{|l|}{ Female } \\
\hline $\mathrm{n}$ & 3848 & 1592 & \\
\hline Age (years) & $63.4 \pm 4.1$ & $64.5 \pm 4.9$ & $<0.001$ \\
\hline Body mass index $\left(\mathrm{kg} / \mathrm{m}^{2}\right)$ & $23.08 \pm 2.85$ & $25.76 \pm 3.19$ & $<0.001$ \\
\hline Waist circumference $(\mathrm{cm})$ & $74.8 \pm 7.0$ & $82.5 \pm 7.6$ & $<0.001$ \\
\hline Systolic blood pressure (mmHg) & $126.4 \pm 18.0$ & $139.7 \pm 17.6$ & $<0.001$ \\
\hline Diastolic blood pressure (mmHg) & $72.0 \pm 10.3$ & $78.3 \pm 10.5$ & $<0.001$ \\
\hline Fasting plasma glucose (mg/dL) & $97.8 \pm 15.5$ & $108.5 \pm 25.3$ & $<0.001$ \\
\hline Total cholesterol (mg/dL) & $213.8 \pm 36.7$ & $216.8 \pm 37.9$ & 0.007 \\
\hline HDL-C (mg/dL) & $63.5 \pm 14.7$ & $48.9 \pm 11.7$ & $<0.001$ \\
\hline LDL-C (mg/dL) & $129.6 \pm 33.6$ & $133.5 \pm 33.9$ & $<0.001$ \\
\hline Triglyceride (mg/dL) & $103.3 \pm 44.5$ & $171.3 \pm 72.1$ & $<0.001$ \\
\hline Log TG & $1.98 \pm 0.17$ & $2.20 \pm 0.18$ & $<0.001$ \\
\hline Haemoglobin $(\mathrm{g} / \mathrm{dL})$ & $13.28 \pm 0.98$ & $13.53 \pm 1.06$ & $<0.001$ \\
\hline
\end{tabular}

MetS (-), without metabolic syndrome; MetS (+), with metabolic syndrome; HDL-C, high-density lipoprotein cholesterol; LDL-C, low-density lipoprotein cholesterol; $\log$ TG, $\log$ transformation of triglyceride. Data are shown as mean $\pm \mathrm{SD}$

Table 2: The univariant and multivariant analyses of haemoglobin and metabolic syndrome related component

\begin{tabular}{|c|c|c|c|c|}
\hline & \multicolumn{2}{|c|}{ Univariant } & \multicolumn{2}{|c|}{ Multivariant } \\
\hline & $\mathbf{R}$ & $p$ & $\boldsymbol{\beta}$ & $p$ \\
\hline \multicolumn{5}{|l|}{ Male } \\
\hline Age & -0.183 & $<0.001$ & -0.151 & $<0.001$ \\
\hline Body mass index & 0.215 & $<0.001$ & 0.060 & $<0.020$ \\
\hline Waist circumference & 0.209 & $<0.001$ & 0.111 & $<0.001$ \\
\hline Systolic blood pressure & 0.066 & $<0.001$ & -0.060 & 0.003 \\
\hline Diastolic blood pressure & 0.157 & $<0.001$ & 0.140 & $<0.001$ \\
\hline Fasting plasma glucose & 0.084 & $<0.001$ & 0.035 & 0.009 \\
\hline High-density lipoprotein & -0.045 & 0.001 & 0.063 & $<0.001$ \\
\hline Low-density lipoprotein & 0.128 & $<0.001$ & 0.098 & $<0.001$ \\
\hline Triglyceride & 0.178 & $<0.001$ & 0.128 & $<0.001$ \\
\hline
\end{tabular}

Female

\begin{tabular}{lrrrr}
\hline Age & -0.088 & $<0.001$ & -0.101 & $<0.001$ \\
Body mass index & 0.131 & $<0.001$ & 0.040 & 0.047 \\
Waist circumference & 0.109 & $<0.001$ & 0.050 & 0.028 \\
Systolic blood pressure & 0.087 & $<0.001$ & 0.034 & 0.076 \\
Diastolic blood pressure & 0.153 & $<0.001$ & 0.142 & $<0.001$ \\
Fasting plasma glucose & 0.149 & $<0.001$ & 0.115 & $<0.001$ \\
High-density lipoprotein & 0.006 & 0.662 & - & - \\
Low-density lipoprotein & 0.136 & $<0.001$ & 0.111 & $<0.001$ \\
Triglyceride & 0.123 & $<0.001$ & 0.114 & $<0.001$ \\
\hline
\end{tabular}

Table 3: Logistic regression of baseline haemoglobin in developing metabolic syndrome and non-fatal cardiovascular disease in the followup period

(a) Metabolic syndrome

\begin{tabular}{|c|c|c|}
\hline Male & Hazard ratio & $p$ \\
\hline Haemoglobin $(>14.6 \mathrm{~g} / \mathrm{dL})$ & $1.186(1.026-1.370)$ & 0.021 \\
\hline Waist circumference $(\geq 90 \mathrm{~cm})$ & $1.629(1.323-2.006)$ & $<0.001$ \\
\hline \multicolumn{3}{|l|}{ Blood pressure (SBP $\geq 130$ or DBP } \\
\hline$\geq 85 \mathrm{mmHg})$ & $1.995(1.715-2.321)$ & $<0.001$ \\
\hline Fasting plasma glucose ( $\geq 100$ mg/dL) & $1.820(1.568-2.113)$ & $<0.001$ \\
\hline High-density lipoprotein $(<50 \mathrm{mg} / \mathrm{dL})$ & $2.322(1.918-2.812)$ & $<0.001$ \\
\hline Triglyceride $(\geq 150 \mathrm{mg} / \mathrm{dL})$ & $2.458(2.043-2.957)$ & $<0.001$ \\
\hline \multicolumn{3}{|l|}{ Female } \\
\hline Haemoglobin $(>13.7 \mathrm{~g} / \mathrm{dL})$ & $1.191(1.045-1.358)$ & 0.009 \\
\hline Waist circumference $(\geq 80 \mathrm{~cm})$ & $1.854(1.543-2.227)$ & $<0.001$ \\
\hline \multicolumn{3}{|l|}{ Blood pressure (SBP $\geq 130$ or DBP } \\
\hline$\geq 85 \mathrm{mmHg})$ & $1.666(1.448-1.917)$ & $<0.001$ \\
\hline Fasting plasma glucose ( $\geq 100$ mg/dL) & $2.135(1.847-2.468)$ & $<0.001$ \\
\hline High-density lipoprotein (<40 mg/dL) & $2.422(2.055-2.854)$ & $<0.001$ \\
\hline Triglyceride $(\geq 150 \mathrm{mg} / \mathrm{dL})$ & $2.412(2.013-2.891)$ & $<0.001$ \\
\hline \multicolumn{3}{|l|}{ (b) Non-fatal cardiovascular disease } \\
\hline & Male & $p$ \\
\hline Haemoglobin $(>14.6 \mathrm{~g} / \mathrm{dL})$ & $1.149(0.902-1.465)$ & 0.261 \\
\hline Waist circumference $(\geq 90 \mathrm{~cm})$ & $1.358(0.950-1.942)$ & 0.094 \\
\hline \multicolumn{3}{|l|}{ Blood pressure $(\mathrm{SBP} \geq 130$ or $\mathrm{DBP}$} \\
\hline$\geq 85 \mathrm{mmHg})$ & $1.759(1.381-2.241)$ & $<0.001$ \\
\hline Fasting plasma glucose $(\geq 100 \mathrm{mg} / \mathrm{dL})$ & $0.942(0.731-1.215)$ & 0.647 \\
\hline High-density lipoprotein $(<50$ mg/dL) & $1.302(0.897-1.891)$ & 0.166 \\
\hline Triglyceride $(\geq 150 \mathrm{mg} / \mathrm{dL})$ & $1.204(0.825-1.757)$ & 0.335 \\
\hline Female Haemoglobin $(>13.7 \mathrm{~g} / \mathrm{dL})$ & $1.293(1.010-1.656)$ & 0.042 \\
\hline Waist circumference $(\geq 80 \mathrm{~cm})$ & $1.302(0.962-1.763)$ & 0.088 \\
\hline \multicolumn{3}{|l|}{ Blood pressure (SBP $\geq 130$ or DBP } \\
\hline$\geq 85 \mathrm{mmHg})$ & $1.706(1.339-2.174)$ & $<0.001$ \\
\hline Fasting plasma glucose ( $\geq 100 \mathrm{mg} / \mathrm{dL})$ & $1.091(0.828-1.436)$ & 0.536 \\
\hline High-density lipoprotein $(<40 \mathrm{mg} / \mathrm{dL})$ & $1.471(1.067-2.026)$ & 0.018 \\
\hline Triglyceride $(\geq 150 \mathrm{mg} / \mathrm{dL})$ & $1.014(0.661-1.555)$ & 0.950 \\
\hline
\end{tabular}

The Hb levels were significantly different in both genders with and without MetS. Except the HDL-C in the females, all the components of MetS and LDL-C were associated with $\mathrm{Hb}$ in the univariant analyses. Moreover, SBP failed to show any significance in the multivariant analyses only in the females. The cut-off point for $\mathrm{Hb}$ is shown in Figure 2 with area under curve (AUC) of 0.585 in the males and 0.575 in the females. 

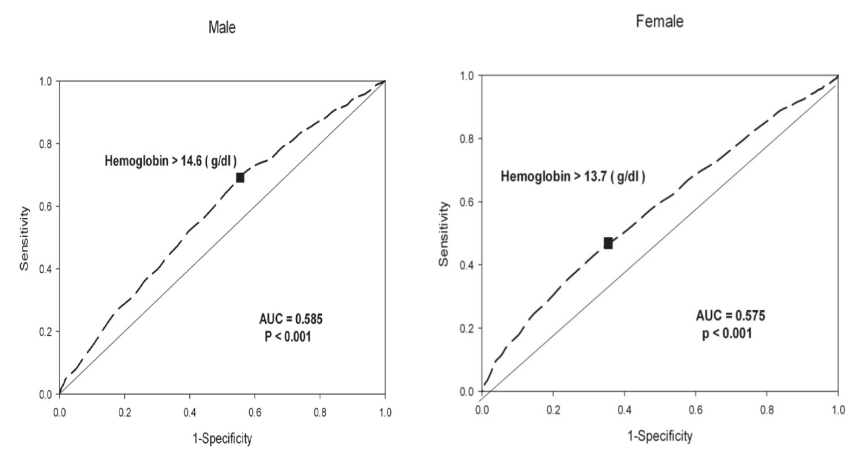

Fig. 2: Receiver operating characteristic (ROC) analysis showed that the estimated optimal cut-off value of haemoglobin in predicting metabolic syndrome.

Although the AUC was not good, it should be pointed out that this study's participants were healthier than the usual study population. Therefore, we lost the extreme end of the data to provide a higher AUC in the prediction of MetS. In the second part of this study, $\mathrm{Hb}$ was shown to be a good predictor of MetS in both genders with HR of $1.186(1.026-1.370)$ in the men and $1.191(1.045-1.358)$ in the women. The same results were seen in the Kaplan-Meier plot. Moreover, Hb was also a good predictor of future CVD in women with HR of 1.293 (1.010-1.656) and log rank test with $p$-value of 0.016 .

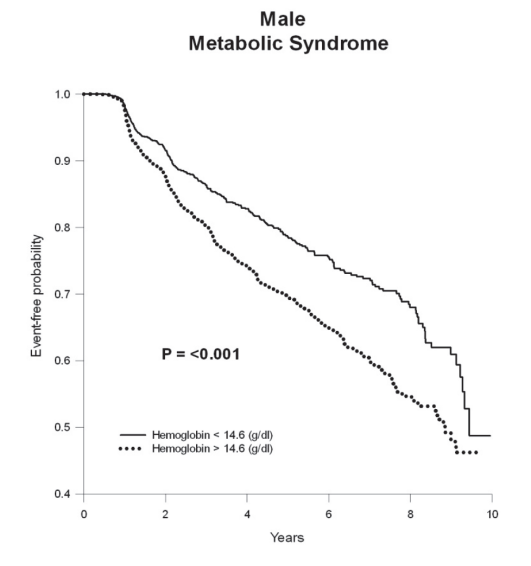

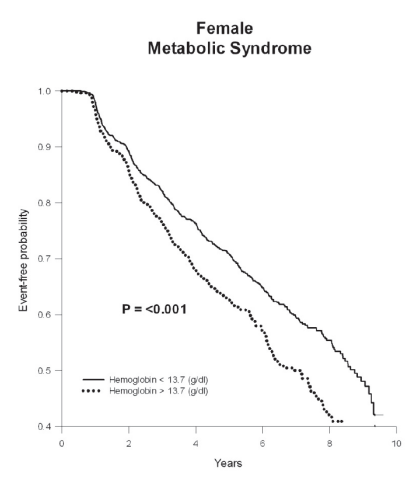

(a) Non-fatal cardiovascular disease

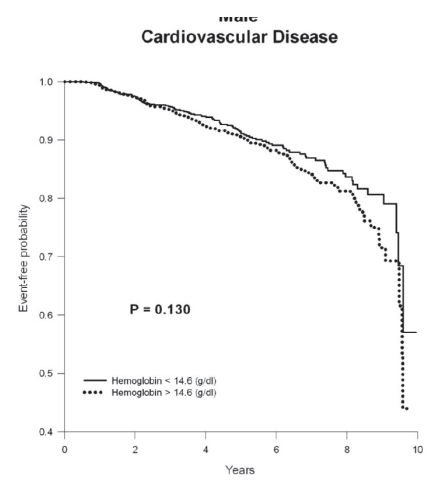

(b) non-fatal cardiovascular disease during follow-up according to the haemoglobin at Baseline (c) Metabolic syndrome

Fig. 3: Kaplan-Meier estimates of (a) metabolic syndrome and (b) non-fatal cardiovascular disease during follow-up according to the haemoglobin at Baseline (c) Metabolic syndrome.

\section{DISCUSSION}

This study showed that $\mathrm{Hb}$ was significantly higher in the group with MetS than in the one without MetS. Moreover, a higher $\mathrm{Hb}$ level was associated with nearly all the components of MetS with the exception of HDL and SBP in the female sample. We further followed up the non-MetS group. The results demonstrated that $\mathrm{Hb}$ level above 14.6 and $13.7 \mathrm{pm} / \mathrm{dL}$ for the males and females, respectively, had a greater chance of having MetS. Elevated $\mathrm{Hb}$ level also has been shown to increase the risk for non-fatal CVD in the female but not in the male population.

Many observational studies have revealed the correlation between elevated $\mathrm{Hb}$ with MetS (10, 13-15). However, currently, there is no evidence suggesting that elevated $\mathrm{Hb}$ would lead to the development of MetS. Therefore, exactly how an elevated $\mathrm{Hb}$ level contributes to the development of MetS remains to be elucidated. Nevertheless, many observations made from previous studies might shed some light on the possible explanations. Studies have shown that increased oxidation and reduced oxygenation in the adipocyte of patients with central obesity, provide a possible underlying mechanism for insulin resistance $(16,17)$. Insulin resistance or a hyperin-sulin state is known to be the main pathogenic process behind MetS (18). Meanwhile, the overexpression of erythropoietin (EPO) gene transcription stimulating factor HIF-1 was also found in the adipose tissue of obese subjects $(17,19)$. Erythropoietin serves as a strong stimulator for red blood cell production, subsequently resulting in elevated $\mathrm{Hb}$ level (20). Therefore, this concurrent pathogenesis of erythropoesis and insulin resistance from adipocytes of patients with central obesity, may explain the correlation between elevated $\mathrm{Hb}$ and $\operatorname{MetS}(9,10,21)$. 
Furthermore, insulin has a synergistic effect with erythropoetin on erythropoesis (21). Although the above mentioned mechanism could well explain the correlation between $\mathrm{Hb}$ and MetS, how $\mathrm{Hb}$ contributes to the development of MetS still requires further investigations.

Another finding of the present study was the association of elevated $\mathrm{Hb}$ level as a risk factor for CVD in the female sample. This finding supports a recent prospective cohort study of 114159 subjects which has shown the association between $\mathrm{Hb}$ and the risk of acute myocardial infarction (22). The pathophysiological explanation for this observation may be that high $\mathrm{Hb}$ concentrations can increase blood viscosity; subsequently, it can increase coronary vascular resistance, decrease coronary blood flow and predispose the patients to thrombosis (11). In addition, elevated red blood cell count has been shown to be an independent predictor of acute cardiovascular event such as stroke or myocardial infarction (23). Further investigations, however, are required to clarify why, in our study, only the females with elevated HB were susceptible to CVD and not the males.

Haemoglobin was significantly correlated with either SBP or DBP in many studies (24-28). This may be due to the effect of insulin on erythropoiesis, which activates tyrosine kinase in the insulin receptor that is essential for the growth-promoting action of insulin (29). The results here are similar to the previously mentioned findings except for their failure to demonstrate the correlation between SBP and $\mathrm{Hb}$ in females. This may be due to the age difference in the present study. Arterial stiffness is known to occur with increasing age and may influence the relationship between $\mathrm{Hb}$ and SBP in elderly men. Meanwhile, HDL becomes insignificant after multivariate regression analyses with elderly women were inconsistent with those reported in other studies (30). Despite the factor of age, all other studies enrolled study participants on medication. The strict exclusion criteria of the present study reflect the true relationship between MetS components that are different from the other studies in the available literature. Again, there is still a need to further investigate the gender differences recorded in this study.

This study, to our knowledge, is the first longitudinal study to establish that elevated $\mathrm{Hb}$ is a risk factor for developing MetS. However, there are many limitations in this study. One limitation was the population selection. This study was based on the Taiwanese population; thus, the findings in this study may not apply to other ethnic groups. Moreover, this study enrolled subjects from a health-screening centre which may have selection bias for the higher social economic status. Another limitation is not addressing smoking as a confounding factor. Smoking is a common cause of elevated haemoglobin level and is also a risk factor for MetS. This information nevertheless was not available for all our patients and therefore was not included in our study as an adjusting variable. However, the large number of this study's participants might reduce this bias.

\section{CONCLUSION}

This study suggests that elevated $\mathrm{Hb}$ increases the risk for developing MetS and it also increases the risk of developing CVD in females. The cut-off value for $\mathrm{Hb}$ was 14.6 and 13.7 for older males and females, respectively; therefore, haemoglobin can potentially be used as a marker to stratify the risks of developing MetS for both genders and CVD in the female population. Further studies are required to elucidate how elevated $\mathrm{Hb}$ contributes directly to the development of MetS and CVD.

\section{AUTHORS' NOTE}

All authors had no conflict of interest in the current study.

\section{REFERENCES}

1. Eckel RH, Grundy SM, Zimmet PZ. The metabolic syndrome. The Lancet 2005; 365: 1415-28.

2. Detection EPO. Evaluation, and treatment of high blood cholesterol in adults. Executive summary of the third report of The National Cholesterol Education Program (NCEP) Expert panel on detection, evaluation, and treatment of high blood cholesterol in adults (Adult Treatment Panel III). Jama 2001; 285: 2486-97.

3. Alberti K, Eckel RH, Grundy SM, Zimmet PZ, Cleeman JI, Donato KA et al. Harmonizing the Metabolic Syndrome A Joint Interim Statement of the International Diabetes Federation Task Force on Epidemiology and Prevention; National Heart, Lung, and Blood Institute; American Heart Association; World Heart Federation; International Atherosclerosis Society; and International Association for the Study of Obesity. Circulation 2009; 120: 1640-5.

4. Ford ES, Li C, Sattar N. Metabolic Syndrome and Incident Diabetes Current state of the evidence. Diabetes Care 2008; 31: 1898-904.

5. Galassi A, Reynolds K, He J. Metabolic syndrome and risk of cardiovascular disease: a meta-analysis. Am J Med 2006; 119: 812-9.

6. Park Y-W, Zhu S, Palaniappan L, Heshka S, Carnethon MR, Heymsfield SB. The metabolic syndrome: prevalence and associated risk factor findings in the US population from the Third National Health and Nutrition Examination Survey, 1988-1994. Arch Internal Med 2003; 163: 427.

7. Lee JG, Lee S, Kim YJ, Jin HK, Cho BM, Kim YJ et al. Multiple biomarkers and their relative contributions to identifying metabolic syndrome. Clinica Chimica Acta 2009; 408: 50-5.

8. Kim J-K, Lee Y-J, Lee J-W, Lee J-H, Shim J-Y, Lee D-C et al. Association between white blood cell and red blood cell counts within reference range and metabolic syndrome in Korean men and women. Toxicology and Environmental Health Sciences. 2010; 2: 238-44.

9. Mardi T, Toker S, Melamed S, Shirom A, Zeltser D, Shapira I et al. Increased erythropoiesis and subclinical inflammation as part of the metabolic syndrome. Diabetes research and clinical practice 2005; 69: 249-55.

10. Hamalainen P, Saltevo J, Kautiainen H, Mantyselka P, Vanhala M. Erythropoietin, ferritin, haptoglobin, hemoglobin and transferrin receptor in metabolic syndrome: a case control study. Cardiovasc Diabetol 2012; 11: 116.

11. Sabatine MS, Morrow DA, Giugliano RP, Burton PB, Murphy SA, Mc$\mathrm{Cabe} \mathrm{CH}$ et al. Association of hemoglobin levels with clinical outcomes in acute coronary syndromes. Circulation 2005; 111: 2042-9.

12. Department of Health EY, R.O.C. (Taiwan). Available at http://www. doh.gov.tw/CHT2006/DM/DM2_p01.aspx?class_no=25\&now_fod_list no $=5912 \&$ level_no $=2 \&$ doc_no $=22602$. Accessed Febuary 10, $201 \overline{3}$.

13. Laudisio A, Bandinelli S, Gemma A, Ferrucci L, Antonelli Incalzi R. Metabolic Syndrome and Hemoglobin Levels in Elderly Adults: The Invecchiare in Chianti Study. J Am Geriatrics Society. 2013; 61: 963-8.

14. Lohsoonthorn V, Jiamjarasrungsi W, Williams MA. Association of hematological parameters with clustered components of metabolic syndrome among professional and office workers in Bangkok, Thailand. Diabetes and Metabolic Syndrome: Diabetes Metab Syndr 2007; 1: 143-9. 
15. Wang Y-Y, Lin S-Y, Liu P-H, Cheung BM, Lai W-A. Association between hematological parameters and metabolic syndrome components in a Chinese population. J Diabetes and its complications 2004; 18: 322-7.

16. Wood IS, de Heredia FP, Wang B, Trayhurn P. Cellular hypoxia and adipose tissue dysfunction in obesity. Proc Nutr Soc 2009; 68: 370-7.

17. Pasarica M, Sereda OR, Redman LM, Albarado DC, Hymel DT, Roan LE et al. Reduced adipose tissue oxygenation in human obesity evidence for rarefaction, macrophage chemotaxis, and inflammation without an angiogenic response. Diabetes 2009; 58: 718-25.

18. Després J-P, Lemieux I. Abdominal obesity and metabolic syndrome. Nature 2006; 444: 881-7.

19. Cancello R, Henegar C, Viguerie N, Taleb S, Poitou C, Rouault C et al Reduction of macrophage infiltration and chemoattractant gene expression changes in white adipose tissue of morbidly obese subjects after surgery-induced weight loss. Diabetes 2005; 54: 2277-86.

20. Jelkmann W. Erythropoietin: structure, control of production, and function. Physiol Rev 1992; 72: 449-89.

21. Barbieri M, Ragno E, Benvenuti E, Zito G, Corsi A, Ferrucci L et al. New aspects of the insulin resistance syndrome: impact on haematological parameters. Diabetologia 2001; 44: 1232-7.

22. Holme I, Aastveit AH, Hammar N, Jungner I, Walldius G. High blood hemoglobin concentration as risk factor of major atherosclerotic cardiovascular events in 114,159 healthy men and women in the Apolipoprotein MOrtality RISk study (AMORIS). Annals of medicine 2012; 44: 476-86.

23. Lowe G, Lee A, Rumley A, Price J, Fowkes F. Blood viscosity and risk of cardiovascular events: the Edinburgh Artery Study. Br J Haematol 1997; 96: $168-73$.
24. Atsma F, Veldhuizen I, de Kort W, van Kraaij M, Pasker-de Jong P, Deinum $\mathrm{J}$ et al. Hemoglobin level is positively associated with blood pressure in a large cohort of healthy individuals. Hypertension 2012; 60: 936-41.

25. Gobel BO, Schulte-Gobel A, Weisser B, Glanzer K, Vetter H, Dusing R. Arterial blood pressure. Correlation with erythrocyte count, hematocrit, and hemoglobin concentration. Am J Hypertension 1991; 4: 14-9.

26. Marketou M, Patrianakos A, Parthenakis F, Zacharis E, Arfanakis D, Kochiadakis $\mathrm{G}$ et al. Systemic blood pressure profile in hypertensive patients with low hemoglobin concentrations. Int J Cardiol 2010; 142: 95 6.

27. Rohlfs RJ, Bruner E, Chiu A, Gonzales A, Gonzales ML, Magde D et al. Arterial blood pressure responses to cell-free hemoglobin solutions and the reaction with nitric oxide. J Biol Chem 1998; 273: 12128-34.

28. Inrig JK, Sapp S, Barnhart H, Patel UD, Reddan D, Singh A et al. Impact of higher hemoglobin targets on blood pressure and clinical outcomes: a secondary analysis of CHOIR. Nephrol Dial Transplant 2012; 27: 3606-14.

29. Lee YJ, Shin YH, Kim JK, Shim JY, Kang DR, Lee HR. Metabolic syndrome and its association with white blood cell count in children and adolescents in Korea: the 2005 Korean National Health and Nutrition Examination Survey. Nutrition, metabolism, and cardiovascular diseases: NMCD 2010; 20: 165-72.

30. Nebeck K, Gelaye B, Lemma S, Berhane Y, Bekele T, Khali A et al. Hematological parameters and metabolic syndrome: findings from an occupational cohort in Ethiopia. Diabetes Metab Syndr 2012; 6: 22-7. 